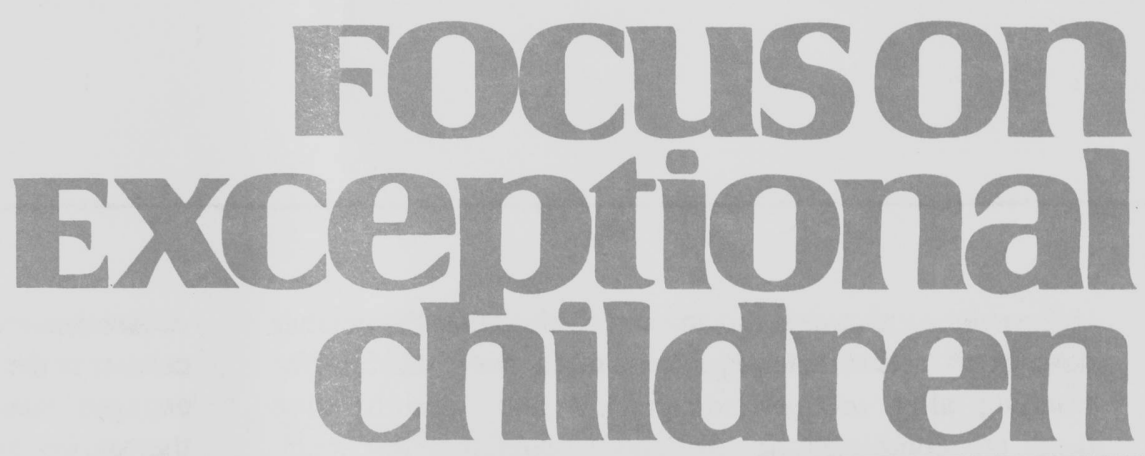

\title{
Engaged Time in the Classroom
}

Beverly H Johns, E. Paula Crowley, and Eleanor Guetzloe

A. J. is a very bright fifth grader who is enrolled in a regular classroom and now has been referred for emotional and behavioral disorders because of his acting out and aggressive behavior. The school psychologist observes A. J. in the classroom. The second-year teacher, who is struggling with lesson planning, provides lectures, during which A. J. is very attentive. The teacher then gives the students an independent practice sheet; she anticipates that the students will need 30 minutes to complete the sheet. A. J. completes the assignment within 5 minutes, has nothing to do, and starts to verbally pick on other students about how slow they are. The other students then call A. J. names. A. J. gets up and proceeds to "get in" the others' faces and yells at them.

\section{THE IMPORTANCE OF ENGAGED TIME}

Foremost in an effective curriculum for students with E/BD is a high level of engaged time-time spent doing meaningful learning activities. If A. J. had been busy, he would not have had time to get into trouble.

Winn, Menlove, and Zsiray (1997) stated that the link between time and learning is one of the most consistent findings in educational research. Wise allocation and the productive use of time increase the likelihood that greater student learning will take place. Unfortunately, schedules often control the school and drive the curriculum. In those situations, students and learning, which should be the focus of the school and the classroom, are often sacrificed to schedules. Kauchak and Eggen (1993) defined the following terms: allocated time, instructional time, engaged time (time-on-task), and academic learning time.

Allocated time is the amount of time that a teacher designates for a topic. For instance, the teacher may allow 55 minutes for social studies or 75 minutes for mathematics.

Beverly H. Johns is an adjunct instructor at MacMurray College. E. Paula Crowley is a professor of Special Education at Illinois State University. Eleanor Guetzloe is a professor of Education at the University of South Florida. This article is adapted from Effective Curriculum for Students With Emotional and Behavioral Disorders: Reaching Them Through Teaching Them, published by Love Publishing Company, 2002. 
Instructional time is the amount of time that the teacher devotes to active teaching. It is often the time left for teaching after routine management and administrative tasks are completed. In all school programs, too much learning time is lost in counting lunch money, waiting for school buses, waiting to go to lunch, and taking restroom breaks. Although these nonengaged times often give teachers breaks, they also provide opportunities for students with behavioral problems to get into trouble. All teachers must look at the amount of "down time" that occurs during a school day and do all that is possible to reduce that time dramatically.

Engaged time (time-on-task) is the portion of instructional time that students spend directly involved in learning activities. Walker and Severson (1992) defined the following components of academic engaged time: (a) The student is attending to the material and the task, (b) the student is making appropriate motor responses (e.g., writing), and (c) the student is asking for assistance in an acceptable manner.

\section{Focuson
Exceptional
childiren}

ISSN 0015-511X FOCUS ON EXCEPTIONAL CHILDREN (USPS 203-360) is published monthly except June, July, and August as a service to teachers, special educators, curriculum specialists, administrators, and those concerned with the special education of exceptional children. This publication is annotated and indexed by the ERIC Clearinghouse on Handicapped and Gifted Children for publication in the monthly Current Index to Journals in Education (CIJE) and the quarterly index, Exceptional Children Education Resources (ECER). The full text of Focus on Exceptional Children is also available in the electronic versions of the Education Index. It is also available in microfilm from Serials Acquisitions, National Archive Publishing Company, P.O. Box 998, Ann Arbor, MI 48106-0998. Subscription rates: individual, \$48 per year; institutions, \$66 per year. Copyright (C) 2008, Love Publishing Company. All rights reserved. Reproduction in whole or part without written permission is prohibited. Printed in the United States of America. Periodical postage is paid at Denver, Colorado. POSTMASTER: Send address changes to:

Love Publishing Company

Executive and Editorial Office P.O. Box 22353

Denver, Colorado 80222

Telephone (303) 221-7333

\section{EDITORIAL BOARD}

Lisa Dieker

University of Central Florida
Paula Maccini University of Maryland

Marleen Pugach

University of Wisconsin-Milwaukee

Carrie E. Watterson

Senior Editor
Stanley F. Love

Publisher
Academic learning time combines engagement and success. It is the amount of time students are successful while engaged. Kauchak and Eggen (1993) summarized research that showed students in classes where success was the dominant pattern not only learned but also felt better about themselves and the material being learned.

Effective teachers of students with $\mathrm{E} / \mathrm{BD}$ understand the importance of the time-on-task variable and realize that the time the students spend engaged in meaningful activities must provide them with a high degree of success. To assure that students can meet with a high degree of success, the teacher must engage in systematic planning and use academic materials that are appropriate for the students' performance level. Much of the research done on effective instruction has used academic engaged time as the measure of students' use of time and the appropriateness of the curriculum (Gunter \& Denny, 1998). Gunter and Denny noted further that engagement is an important component of academic performance.

A recent study by Depaepe, Shores, Jack, and Denny (1996) noted the importance of a high degree of time-ontask coupled with effective instructional strategies that matched academic materials to students' performance levels. This high degree of time-on-task and appropriate instructional strategies may represent an additional means of decreasing disruptive behavior in the classroom and may promote gains in academic performance of students.

Carpenter and McKee-Higgins (1996) cited research that has shown that one of the essential components for the creation of a positive class climate is a high rate of student academic involvement and achievement in which the content of the curriculum and instructional delivery focus on high rates of student engagement during instruction and practice.

Engaged time-on-task is directly related to higher levels of student achievement. Reavis et al. (1996) reported that students should be spending at least $70 \%$ of their time on engaged academic tasks.

Mastropieri and Scruggs (1994) believe that the most important teacher-effectiveness variable is time-on-task. According to them, time-on-task can be broken down into allocated and engaged time. Allocated time refers to the 40minute block of time that the teacher has scheduled for a reading activity. However, engaged time refers to the actual time that the students are engaged in instructional activities. During engaged time students are actively involved in areas that are directly relevant to instructional objectives. Involvement is evidenced by eye contact with the teacher, active attention to teacher presentation, direct responses to teacher questions, and active engagement with relevant and appropriate instructional materials. Nonengaged activities include those that do not require active student participation and that are not directly relevant to instructional objectives (transition 
activities such as sharpening pencils, making announcements, student conversation not directly relevant to instructional objectives, and time spent on disciplinary actions such as reprimands). Teachers should continually work toward keeping nonengaged time to a minimum.

A teacher can record engaged versus nonengaged time by creating a worksheet in which the day is divided into 15minute segments and recording just how much time is devoted to engaged activities (see Figure 1).

Montague, Bergeron, and Lago-Delello (1997) suggested ways to increase the amount of academic engaged time: (a) Give explicit and direct instructions before the assignment of the task to ensure that students know what to do, (b) monitor progress by providing frequent positive reinforcement and corrective feedback during the activities, and (c) reward students for completing tasks.

Stewart, Evans, and Kaczynski (1997) reported on the importance of time and instructional management. They advocated that the teacher analyze the use of academic and nonacademic time in the classroom and compare the results to a model schedule that allows for maximum efficiency.

\section{Transition Times}

Mastropieri and Scruggs (1994) summarized research that shows that transitions constitute a major source of offtask activities. Transition refers to intervals during which students move from one class or group or from one subject to another. During these times behaviors such as sharpening pencils, talking to classmates, or obtaining drinks at the water fountain may occur. Teachers should plan for these activities to occur at prespecified times during the day rather than during a specified engaged-time activity. Likewise teachers should establish an expectation that students move from one activity to another quickly, quietly, and efficiently. Students should be reinforced for making transitions smoothly.

Some suggestions for handling transitions include (a) adhere to a schedule so that students know when the transitions

\begin{tabular}{ll}
\hline 8:30 a.m. & $-8: 45$ a.m. \\
8:45 a.m. & $-9: 00$ a.m. \\
9:00 a.m. & $-9: 15$ a.m. \\
9:15 a.m. & $-9: 30$ a.m. \\
9:30 a.m. & $-9: 45$ a.m. \\
9:45 a.m. & $-10: 00$ a.m. \\
10:00 a.m. & $-10: 15$ a.m. \\
10:15 a.m. & $-10: 30$ a.m. \\
10:30 a.m. & $-10: 45$ a.m. \\
10:45 a.m. & $-11: 00$ a.m. \\
11:00 a.m. & $-11: 15$ a.m. \\
11:15 a.m. & $-11: 30$ a.m. \\
11:30 a.m. & $-11: 45$ a.m. \\
11:45 a.m. & $-12: 00$ p.m. \\
12:00 p.m. & $-12: 15$ p.m. \\
12:15 p.m. & $-12: 30$ p.m. \\
12:30 p.m. & $-12: 45$ p.m. \\
12:45 p.m. & $-1: 00$ p.m. \\
1:00 p.m. & $-1: 15$ p.m. \\
1:15 p.m. & $-1: 30$ p.m. \\
1:30 p.m. & $-1: 45$ p.m. \\
1:45 p.m. & $-2: 00$ p.m. \\
2:00 p.m. & $-2: 15$ p.m. \\
2:15 p.m. & $-2: 30$ p.m.
\end{tabular}


will occur, (b) announce to students in advance that there will be a change so that students know what to expect, (c) have materials ready before the transition begins, and (d) establish routines.

\section{Practical Classroom Suggestion}

Teachers should provide students who frequently ask to use the restroom or to sharpen pencils or engage in other offtask activities with a specified number of coupons for those activities. Each time the students wish to do the activity, they must forfeit a coupon. When all coupons are gone, the students can no longer request that activity. Such a system teaches students to budget their time and activities.

\section{Accurate Teacher Scheduling}

Being able to schedule properly and ensure that the task can be accomplished in the time allotted is very difficult for some beginning teachers. They will plan an activity that they think will take 30 minutes and discover that the students have completed the task in 10 minutes and now have 20 minutes left with nothing to do but get into trouble. Teachers must learn to gauge the approximate amount of time that the activity will take and then have contingency plans such as extra-credit or bonus work for students who finish early. It is important that the extra-credit or bonus work be related to the skill the teacher is trying to teach. It is also recommended that the additional activities utilize higher-level thinking skills. Busy work, such as coloring a picture about the topic or completing a simple word find, does little to challenge the student. Teachers will find it helpful to plan too many rather than too few lessons.

\section{Analysis of Worksheets}

For any worksheet assignment or group lesson, the teacher should determine the reason for teaching the material and the relevance for the particular student(s). In many classes, students are involved in busy work-worksheets that have little relevance to what they need to know or want to learn. In many classrooms, worksheets are assigned that are not even related to the topic. In this article, we show you multiple ways to increase engagement other than through the use of worksheets.

Students who find worksheets and assignments meaningless and view them as busy work become unmotivated to come to school. They often ask: "Why do I have to learn this, anyway?" or "How many more multiplication problems do I have to do on this sheet of paper?" Too many teachers have students do busy work because it requires less planning than appropriately developed activities. However, work that is not relevant to students can result in behavioral problems, which in turn will result in more work for the teacher.
Braukman (1995) outlined a hierarchy for the best way to teach the traditional curriculum through real life applications.

1. Being there-taking students to the natural environment where the application of the skill is immediate. Obviously, this approach would involve a high level of engaged time.

2. Immersion or simulation-creating the natural environment within the classroom.

3. Hands-on—students recreate natural learning through manipulatives or involvement in an experience.

4. Second-hand-use of television, videos, or films of the material to be learned. Use of books that relate to the real life experience.

5. Abstract symbolic-teaching in a theoretical mode removed from real life application. Teachers must ask themselves how much of the school day is spent using the abstract symbolic method-the least effective way to teach.

\section{Use of Videos as a Learning Tool}

Some teachers allow students to earn the right to view videos. This practice may be appropriate on a limited basis provided it is not a substitute for teaching. We believe that video rewards should be limited to no more than $1-1 / 2$ or 2 hours at the most per week, unless the video relates to a specific unit being taught and is integrated into the curriculum with planned activities prior to and after its showing. Videos encourage passive learning rather than active learning in which students are engaged in meaningful tasks.

Videos should not be used to simply fill the day. Likewise, only those videos should be shown that have been rated " $G$ " or that have been approved by parents. Videos that depict violations of school or classroom rules should not be shown in the classroom. When teachers do so, they send a mixed message to students that although the school does not allow foul language, it is acceptable to show it on the screen. Obviously, videos that depict violence or inappropriate language should not be shown.

\section{THE DANGERS OF NONENGAGED TIME}

We know that the greater the amount of engaged time on tasks, the higher the achievement levels of the students. Kauchak and Eggen (1993) reported that high-achieving students are typically engaged for $75 \%$ of the time or more while low achievers have engagement rates that are often below $50 \%$. Effective teachers produce on-task rates as high as $80 \%$ while less effective teachers exhibit on-task rates of $60 \%$. If we want to assure higher achievement for our students, we must engage them in meaningful tasks. 
According to Montague, Bergeron, and Lago-Delello (1997), research suggests that students who are not engaged academically most of the time frequently become passive learners, give up easily on tasks, become anxious, withdrawn, angry about school, and fail in future grades.

A low degree of engaged time also creates a vacuum in which students can and will exhibit behavior problems. When students have nothing to do or too much free time, behavioral problems will occur. Such was the case with A. J. Well-run classrooms with high rates of successful engaged time are places in which there are fewer behavior management problems.

Johns and Carr (1995) reported that many students who come to school are passive learners. They are used to watching television and expect to be entertained by the teacher. Although the teacher needs to be a performer, he or she must get students involved in the learning process.

Children learn better by doing than by being told. If we are to motivate students, decrease behavior problems, and ensure their academic success, then we, as educators, must engage them in meaningful tasks. The following section describes multiple ways through which we can engage students in meaningful and fun activities.

\section{TEN CLASSROOM ACTIVITIES TO INCREASE MEANINGFUL STUDENT ENGAGEMENT}

There are many ways that a teacher can increase engaged time for students within the classroom. The following represents some ideas for use with E/BD students.

\section{Response Cards}

Following an explanation of a concept, a teacher asks a variety of questions to determine whether the students have grasped the concept. The teacher asks students to raise their hands if they know the answer. The students who have grasped the concept, who are quick to respond, and who are not shy will immediately raise their hands. The students who do not grasp the concept, who have delayed processing times, or who are shy will not participate. Those students may even put their heads down and hope they are not called on to answer.

An activity that involves all students is the use of response cards. There are many variations of response cards. For young children, the teacher might give each child two popsicle sticks - one with yes on it, the other with no on it. The teacher asks a yes/no question, and each child raises the appropriate popsicle stick. The teacher may also give each child an index card and have each child write down the answer to a question. The teacher may have students stand up if they agree with a teacher statement or stay seated if they do not agree. The teacher might have each child do a thumbs up if he or she agrees or thumbs down if he or she disagrees.

\section{Lecture Bingo}

When a teacher is going to give a lecture, the teacher can pick out key terms he or she will be discussing in the lecture. The teacher can take a blank bingo card and in each square put one term until the bingo card is filled. Each student gets a bingo card with these terms. Students are instructed to listen closely to the lecture. When they hear one of the terms on the bingo card, they are to mark the bingo square. When a student has completed a line or the whole card (whatever is the teacher preference) the student yells, "Bingo!" This activity keeps the student focused on the key terms in the lecture.

\section{Red Rubber Ball}

A teacher can buy inflatable balls that have squares containing math problems, states, clocks with specific times, and so on. These balls are a great activity for engagement. The students throw the ball up in the air, catch the ball, answer the problem in the square where the left thumb is, and write the answer on paper. I prefer to make my own balls by buying a blank ball (preferably red) and writing questions about the topic being covered in class. Use a permanent marker to print the questions on the ball.

This activity can also be utilized in a team game. The teacher breaks the students into teams. The teacher throws the ball, and a student on the team catches it. The rest of the team has to answer the question, rather than the team member who catches the ball. Again, wherever the left thumb lands is the question that is answered by the team.

\section{Pick Your Post}

When the teacher has taught a given amount of material, rather than giving the students a worksheet or a test to measure how much has been learned, the teacher can post sheets of paper at various stations in the room. On one sheet it might state, write a poem; on another, write a song; on another, prepare a skit; on another, draw a picture; on another, make a game. Students then go around the room and "pick your post." Whatever post they pick is the activity that they do. Students can work together in a group on the project.

\section{Carousel Brainstorming}

The teacher puts up five large sheets of paper in locations around the classroom. The teacher writes on each sheet of paper some thought-provoking questions on a topic. The teacher breaks the students into five groups and has each group start at one of the locations. The group is to "brainstorm" solutions to the problems and write down as many 
solutions as they can. When the teacher says, "Move to the next station," all groups move clockwise to the next sheet of paper. The brainstorming process begins again. The teacher does this until all groups have had a chance to brainstorm solutions to all of the problems. Music is sometimes helpful in the activity-when the music starts, the group moves.

\section{Think-Pair-Share}

In this activity, the teacher asks a thought-provoking question. Each student individually writes down what he or she believes is a possible answer. The teacher then breaks the class into pairs. This author breaks students into pairs in a variety of ways: using pairs of colored chips, and the student has to find another student who has the same color chip; using cards where a state is on one card and its capital is on another card, and students find the matching pair. When students have found their partner, they discuss what each one of them answered. After a short, specified amount of time, the teacher has each pair share their responses.

\section{Games}

Students love games, and teachers can increase engagement by developing learning games such as bingo, lotto, jeopardy, concentration, spelling baseball, and so on. If the teacher is going to play team games, he or she must be very careful to match skills on teams so that no child is embarrassed and no team has an unfair advantage over another team.

\section{Dominoes}

This gives students the opportunity to move around and is a great way to check basic understanding of facts. A student will be given a card with a question, and another student will be given a card with the answer to the question. Another student will be given a different question and another the answer to that question. Students have to go around the room to find the individual who has the answer to the question.

\section{Crossword Puzzles and Word Finds}

This is an excellent activity for spelling. The teacher may create the crossword puzzle or the word find, but it can be more fun and engaging for the students to create a puzzle or word find using their spelling words.

\section{0. $\mathrm{K}-\mathrm{W}-\mathrm{L}$}

Bos and Vaughn (1991) discuss the use of KWL. KWL is an excellent way to activate student background knowledge, to find out what the student wants to learn about a given topic, and to check what the student has learned about the topic. The strategy is based on research that stresses the importance of background knowledge in giving meaning during reading. It can be used when a student is beginning to read about a topic, or it can be used when a teacher is introducing a new topic to the class.

The student is given a sheet of paper with three columns. The first column is K: What I know about the topic. The second column is W: What I want to learn about this topic. The third is L: What I learned about the topic. During the " $\mathrm{K}$ " step, the teacher and students engage in a discussion that assists students in thinking about what they already know about the topic being introduced. During the "W" phase, the teacher finds out what may be interesting to the student. In the "L" step, the students write down what they learned after reading about the topic or after it has been discussed in class.

\section{REFERENCES}

Bos, C., \& Vaughn, S. (1991). Strategies for teaching students with learning and behavior problems. Boston: Allyn \& Bacon.

Braukman, D. (1995). The best way to teach. Handout provided at the Learning Disabilities Association of Illinois Convention, October 1995.

Carpenter, S., \& McKee-Higgins, E. (1996). Behavior management in inclusive classrooms. Remedial and Special Education, 17(4), 195-203.

Depaepe, P., Shores, R., Jack, S., \& Denny, R. (1996). Effects of task difficulty on the disruptive and on-task behavior of students with severe behavior disorders. Behavioral Disorders, 21(3), 216-225.

Gunter, P., \& Denny, R. (1998). Trends and issues in research regarding academic instruction of students with emotional and behavioral disorders. Behavioral Disorders, 24(1), 44-50.

Johns, B., \& Carr, V. (1995). Techniques for managing verbally and physically aggressive students. Denver, CO: Love.

Kauchak, D., \& Eggen P. (1993). Learning and teaching. Boston: Allyn and Bacon.

Mastropieri, M., \& Scruggs, T. (1994). Effective instruction for special education, (2nd ed.). Austin: Pro-Ed.

Montague, M., Bergeron, J., \& Lago-Delello, E. (1997). Using prevention strategies in general education. Focus on Exceptional Children, 29(8), 1-12.

Reavis, H., Kukic, S., Jenson, W., Morgan, D., Andrews, D., \& Fisher, S. (1996). BEST practices: Behavioral and educational strategies for teachers. Longmont, CO: Sopris West.

Stewart, S., Evans, W., \& Kaczynski, D. (1997). Setting the stage for success: assessing the instructional environment. Preventing School Failure, 41(2), 53-56.

Walker, H., \& Severson, H. (1992). Systematic screening for behavior disorders. Longmont, CO: Sopris West.

Winn, D., Menlove, R., \& Zsiray, S. (1997). Rethinking the scheduling of school time. Bloomington, IN: Phi Delta Kappa Educational Foundation. 


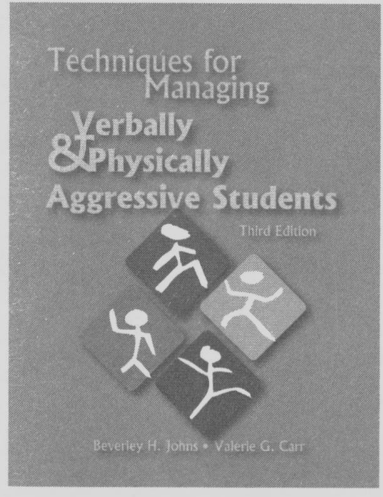

\section{Techniques for Managing Verbally \& Physically Aggressive Students Third Edition}

\section{BEVERLEY H. JOHNS AND VALERIE G. CARR}

The latest edition of this classic book incorporates new strategies for handling violence and inappropriate behavior in our schools, including the implications of new technologies like cell phones, social networking, and cyberbullying. The authors provide how-to information and step-by-step methods for working with disciplinary problems and aggression within the school setting. They focus specifically on techniques for breaking up fights, intervening in bullying, and working with students who talk back and refuse to do their work.

These classroom management techniques provide tangible results. Strategies for school-wide behavior management and community and parent involvement provide an integrated and comprehensive approach to addressing violence in our schools.

\section{LOVE PUBLISHING COMPANY}

9101 East Kenyon Avenue, Suite 2200

Denver, Colorado 80237

303-221-7333 • 303-221-7444 (fax)

\section{CONTENTS}

I. Facing the Challenge

2. The Classroom Climate

3. Ineffective Classroom Management Techniques

4. Successful Behavior Management

5. Behavioral Intervention Plans

6. Understanding Aggression

7. Dealing With Aggressive Behavior

8. Verbally Dealing With Aggression

9. Use of Time-Out

10. Bully-Proofing Your Classroom

II. Dealing With Physical Aggression

12. Breaking Up Fights

I3. Police Intervention and Community Agency Involvement

14. Working Effectively With Parents

15. Administrative Issues

Appendixes

\section{PERMISSIONS AND COPYRIGHT}

All rights are reserved. No part of this publication may be reproduced, photocopied, faxed, stored in a retrieval system, or transmitted in any form or by any means, electronic, mechanical, recording or otherwise, without the prior written permission of the publisher.
Back issues are available for sale. Reproduction requires permission and payment of fees. It is illegal and a violation of federal copyright law to reproduce this publication without permission. Direct all inquiries to the permissions editor. 


\section{INDEX • Volume 40}

Author Index

Blumberg, E. Richard (May 2008)

Carroll, Stuart Z. (May 2008)

Dieker, Lisa (February 2008)

Edge, Denzil (October 2007)

Enguídanos, Tomás (January 2008)

Gagnon, Joseph Calvin (April 2008)

Genzuk, Michael (November 2007)

Hughes, Charles (February 2008)

Hynes, Michael (February 2008)

Knackendoffel, E. Ann (December 2007)

Kroth, Roger L. (October 2007)

Leone, Peter E. (September 2007)

Maccini, Paula (April 2008)

Malmgren, Kimber (April 2008)

Mayer, Matthew J. (September 2007)

Petroff, Jerry G. (May 2008)

Rueda, Robert (November 2007)

Ruiz, Nadeen (January 2008)

Simpson, Richard (March 2008)

Smith, Eileen (February 2008)

Strickland, Tricia (April 2008)

Zirkel, Perry A. (January 2008)

\section{Chronological Index of Titles}

School Violence and Disruption Revisited: Equity and Safety in the School House (September 2007)

Parent-Teacher Conferences (October 2007)

Sociocultural Scaffolding as a Means Toward Academic Self-Regulation: Paraeducators as Cultural Brokers (November 2007)

Collaborative Teaming in the Secondary School (December 2007)

A Legal Roadmap of SBR, PRR, and Related Terms under the IDEA (January 2008)

Shared Reading for Older Emergent Readers in Bilingual Classrooms (January 2008)

Implications of Mixed Reality and Simulation Technologies on Special Education and Teacher Preparation (February 2008)

Children and Youth With Autism Spectrum Disorders: The Search for Effective Methods (March 2008)

Assessing the General Education Math Curriculum for Secondary Students With High-Incidence Disabilities (April 2008)

The Promise of Liberal Learning: Creating a Challenging Postsecondary Curriculum for Youth With Intellectual Disabilities (May 2008) 